\title{
UNUTULAN GAZETE: MARKO PAŞA
}

\section{Emre AYDIN 1}

\section{Özet}

Marko Paşa, yayınlandığı 1946-1950 tarihleri arasında halkın konuşmaktan dahi çekindiği konuları, kendi anlatımıyla ele alış şeklinden dolayı büyük bir beğeni kazanmıştır. Gazete yayınlandığı dönemde sürekli baskılara uğramış ve kapatılma cezası almıştır fakat her seferinde yeni bir isim kullanarak yeniden basın hayatında yer bulmuştur. Marko Paşa yalnızca 4 yıl yayınlanmasına rağmen yine de kayda değer bir başarı göstermiş ancak bu durum gazetenin sonraki yıllarda tanınırlık popülaritesi adına herhangi bir destek sağlamamıştır. Bu durum birçok eleştirmenin de kabul ettiği gibi yalnızca dönem yayını olduğunu, halkın o zaman diliminde böyle bir yeniliğe aç bulunduğunu, sonraki yıllarda yayınlanması durumunda beklenen ilgiye mazhar olamayacağından söz edilir. Bu gazetede çalışan Sabahattin Ali, Rıfat Ilgaz ve Aziz Nesin gibi yazarlar ise zaten Türk basın hayatında derin izler bırakan şahsiyetler olarak tarihte önemli bir yer tutmuştur.

Anahtar Kelimeler: Aziz Nesin, Marko Paşa, Rıfat Ilgaz, Sabahattin Ali

\section{FORGOTTEN NEWSPAPER: MARKO PAŞA}

\section{Abstract}

Marko Paşa gained great appreciation due to its narrative handling the issues that the public did not even talk about between 1946-1950. At the time of its publication, the newspaper was constantly pressured and fined for closure, but each time it found a place in the life of the press again, using a new name. Although Marko Paşa was printed only for 4 years, it achieved a remarkable success, which failed to provide any further steps for the sake of its popularity in the following years. As many critics agree, this is only a periodical publication, the public is hungry for such innovation in that time period, and if it is published in subsequent years, it cannot receive the expected attention. Writers such as Sabahattin Ali, Rifat Ilgaz and Aziz Nesin, who worked in this newspaper, have already taken a significant place in history as personalities who have left deep traces in Turkish press life.

Keywords: Aziz Nesin, Marko Paşa, Rıfat Ilgaz, Sabahattin Ali

\section{Giriş}

Marko Paşa bugün insanlar tarafından çok bilinen bir gazete olmasa da yayınlandığı kısa dönemde en çok basılan ve en çok satılan gazete olduğu gibi halk kitlelerini kendi yanına çekebilecek kadar da güçlü bir gazeteydi. Marko Paşa, Sabahattin Ali başta olmak üzere Aziz Nesin ve Rıfat Ilgaz tarafından ortaya konulan bir siyasi mizah gazetesidir. Yazarların ülke gündemine dair görüşlerinin oluşumunda, tek parti rejiminin II. Dünya Savaşı'nda takip ettiği siyaset ve savaş sonrasında kurulmaya çalışılan çok partili hayata geçiş denemeleri belirleyici olmuştur. İlk başta Türkiye Sosyalist Partisi'nin (TSP)

\footnotetext{
${ }^{1}$ Yüksek Lisans Öğrencisi, Kırşehir Ahi Evran Üniversitesi, Sosyal Bilimler Enstitüsü, Tarih Anabilim Dalı. emreaydincontact@gmail.com 
yayın organı olarak düşünülen gazete partinin kapanması sonrasında bağımsız olarak yayın hayatını sürdürmüştür. $\mathrm{O}$ zamana kadar yayınlanan gazeteler arasında ortalama satış rakamları 30.000'i geçmezken² Marko Paşa 5. sayısından itibaren 60.000 satış rakamına ulaşmıştır. Gazete 1946 ile 1950 yılları arasında yayınlanmıştır. Marko Paşa'nın tek parti rejimine yönelik eleştirileri birçok defa toplatılmasına ve kapatılmasına yol açmış bu nedenle adı geçen gazete yayın hayatına Marko Paşa, Merhum Paşa, Malûm Paşa, Alibaba, Hür Marko Paşa, Yedi-Sekiz Paşa, Hür Marko Paşa (yeni seri) ve Medet gibi isimlerle devam ederek Türk basın hayatındaki mümtaz yerini almıştır.

\section{Marko Paşa Gazetesinin Dönemleri}

Marko Paşa'nın yayınlandığı dönem içinde yaşadığı sıkıntılar ve bu sıkıntılardan kurtulma adına sık sık isim değişikliğine gitmesi bu gazetenin yayın serüveninin anlaşılmasını zorlaştırmıştır. Bu nedenden dolayıdır ki yayın politikasının öğrenilmesini kolaylaştırma adına gazetenin yayın süreci üç döneme ayrılarak incelenmektedir. Birinci dönem Sabahattin Ali'nin içinde bulunduğu yayın dönemini kapsamaktadır. Bu dönemde yayınlanan gazete Marko Paşa, Merhum Paşa, Malûm Paşa ve Alibaba isimleriyle basın hayatında yer bulmuştur. Bu gazetenin birinci döneminde sahipliğini Sabahattin Ali'den sonra Mücap Ofluoğlu ve Mustafa Uykusuz devralmıştır. Merhum Paşa'nın 4 sayısında Sabahattin Ali, Malûm Paşa'nın 5 sayısında Orhan Erkip, Alibaba'nın 3 sayısında Nedim Ofluoğlu, son sayısında ise Rıfat Ilgaz gazetenin sahibi olarak gözükmektedir. Bu dönemde Emek, Tan, Berksoy, Stad, Büyük doğu ve Gutenberg matbaalarında gazete çıkarmaya çalışmışlardır. Alibaba'nın kapanması ile birlikte Sabahattin Ali yurtdışına gitmek istemiş, pasaport vizesi alamamasından dolayı bu durum illegal yoldan gerçekleştirilmeye çalışılmış ancak Sabahattin Ali sınırı geçmeye çalışırken kendisine refakatçi olan Ali Ertekin tarafından öldürülmüştür. Sebahattin Ali'nin öldürülmesiyle Marko Paşa'nın birinci dönemi son bulmuştur.

Marko Paşa'nın 2. dönemi 10 aylık bir beklemeden sonra Cerrahpaşa'da verem hastallğ 1 nedeniyle tedavi gören Rifat Ilgaz'ın, Aziz Nesin'den bir mektup almasıyla başlamıştır ${ }^{3}$. Aziz Nesin mektupta Marko Paşa'nın imtiyaz hakkını elinde bulunduran Orhan Erkip'le konuştuğunu, gazetenin sahibinin Rıfat Ilgaz olması konusunda anlaştığını belirtmiştir. 29 Ekim 1948 tarihinde Marko Paşa aynı isimle 2. dönemine başlamıştır. Illk yayınlanan Marko Paşa ile karıştırılmaması için gazete başlığının alt tarafına“(35)" ibaresi konulmuştur. Bu ibare Marko Paşa'nın bundan önceki yayınlanan 35 sayısına istinaden yapılmıştır. Gerçekte bu "35" rakamı yanlıştır çünkü birinci dönemde Marko

\footnotetext{
21946 seçimlerinde Vatan gazetesinin 50.000 satması gibi bazı istisnalar vardır.

${ }^{3}$ Rıfat Ilgaz, Sarı Yazma, Çınar Yayınları, 1990, İstanbul, s.339.
} 
Paşa “36" sayı yayınlanmıştır. Bu durum yazarlar tarafından fark edilmiş ve 11. sayıda yer alan "(36)" ibaresiyle düzeltilmiştir. Marko Paşa'nın ikinci dönemi, 14 Şubat 1949 tarihinde yayınlanan 16. sayısı ile nihayet bulmuştur. Marko Paşa'nın kapanmasının sebebi, yazarların yabancı devlet yöneticileri ile ilgili yazdıkları haberler yüzünden açılmış davalardır. Bu davalar yazarların aleyhine sonuçlanınca kaçak hayatı yaşamak zorunda kalmışlardır. Marko Paşa'nın ikinci dönemindeki sayıları yalnızca Osmanbey matbaasında basılmıştır. 2. dönemde Marko Paşa'nın 11. sayısıyla birlikte kapanmaya karşı ek olarak Hür Marko Paşa adlı gazete çıkarılmış fakat yalnızca bir sayı yayınlanabilmiştir.

Marko Paşa'nın 3. dönemi aynı adla çıktığı tek sayısıyla1 Nisan 1949 tarihinde başlamaktadır. Bu dönemde gazetenin sahibi olarak Mahmut Kayman gözükmektedir. Bu sayının toplatılması ile birlikte "Yedi-Sekiz Paşa" yayınlanmaya başlanmıştır. Bu dönemde ise gazetenin sahibi olarak Orhan Müstecaplıŏlu ismi geçmektedir. Gazetenin düşük satış gerçekleştirmesinden dolayı 4. sayısında kapatılması kararı alınmış, karar sonrasında yazarlar farklı gazetelerde çalışmaya başlamışlardır. Rıfat Ilgaz 2. dönemde tek sayı yayınlanan Hür Marko Paşa'yı Orhan Erkip müdürlüğü altında yeniden çıkarmaya başlamış, Hür Marko Paşa'nın 6. sayısı ile birlikte Orhan Erkip, gazeteyi Rıfat Ilgaz'a devrederek işten ayrılmıştır. Hür Marko Paşa 12 Eylül 1949 tarihinde yayınladığı 19. sayısıyla kapanmıştır. Kapanma nedeni 2. dönemde yayınlanan "Al Sözünü geriye" adlı yazı sebebiyle açılan davanın Rıfat Ilgaz'ın aleyhinde sonuçlanmış olmasıdır. Yargılama sonucunda Rıfat Ilgaz 1 sene hapis cezasına çarptırılmıştır.

Hür Marko Paşa'nın kadrosunda yer almayan Aziz Nesin 23 Nisan 1950 tarihinde "Medet" adlı gazeteyi çıkarmıştır. Gazetenin sahibi olarak Mefkûr Demiray gözükmektedir. Gazete toplam 25 sayı çıkmıştır. Gazetenin kapanma nedeni 14 Mayıs 1950 tarihli Demokrat Parti'nin (DP) hükümet programinda yer alan 3. maddesinde "mizah veya siyasi tenkit kisvesi altında ayakta tutulmak istenen ve hakikatte düpedüz aşırı sol cereyanları"n"4 kapatılacağı yönündeki açıklamadır. İktidarın değişmesi Marko Paşa'yı rahatlatacak bir durum gibi gözükmesine rağmen yeni kurulan hükümetin kendisini tenkit edici herhangi bir yayın istememesi aşikârdır. Medet, 27 Mayıs 1950 tarihinde yayınladığı 25. sayısı ile birlikte son bulmuştur.

Rıfat Ilgaz'ın sağlık nedenleriyle hapishaneden erken çıkması onun yeniden bir gazete çıkarma kararı almasına vesile olmuştur. Bu karar sonrasında Rıfat Ilgaz'ın arkadaşı olan Raci Hakkı Dinçer'in sahipliği altında Hür Marko Paşa çıkarılmaya başlanmıştır. Diğerinden farklı olabilmesi için

\footnotetext{
${ }_{4}^{4}$ TBMM Tutanak Dergisi, 29 Mayıs 1950, 9. Dönem, Cilt. 1, s.30.
} 
başlığın hemen alt tarafına "Yeni Seri" ibaresi eklenmiştir. İlk sayısını 27 Mart 1950'de çıkaran gazete, 15. ve son sayısını ise 10 Temmuz 1950 tarihinde basmıştır. Gazetenin 11. sayısıyla beraber Rıfat Ilgaz'ın sağlık durumu kötüleşmiş ve hastaneye yatırılmıştır. 4 sayı daha devam eden gazetenin kapanma nedeni Medet ile aynıdır. Her iki gazetenin kapanması bakımından herhangi bir dava açılmamışsa da yazarların kötü durumda bulunmaları ve iktidarın değişmesi için verdikleri çabanın başarılı olması, kendilerini daha fazla zorlamamaları için bir neden olmuştur.

\section{Marko Paşa'nın Önemi}

Marko Paşa'nın yayınlandığı dönem Türkiye Cumhuriyet'inde birçok yeniliğin ortaya çıktığı bir dönemdir. Bu yeniliklerin en başında çok partili hayata geçiş yer almaktadır. Cumhuriyet Halk Partisi (CHP) içinden kopan bir grup, DP adı altında yeni bir parti oluşturmuştur. Marko Paşa yayınlandığı ilk dönemde genel hatlarıyla iktidarda bulunan $\mathrm{CHP}^{\prime}$ ye karşı o zamana kadar görülmemiş sertlikte muhalefet yapmaya çalışmıştır. Bu durum DP adına oldukça iyi gelişmeler sağlayacaktır.

Marko Paşa ve soyundan gelen gazetelerde "Halk için haftalı Siyasi Mizah Gazetesi" ibaresi bulunmaktaydı. Yayınladıkları her sayı halk tarafindan ilgi görüyor hatta bir mizah gazetesi olarak karaborsaya düşüyordu. 5. sayısıyla beraber 60.000 tiraja ulaşan gazete, bu başarıyı adeta standart haline getirdi ve bu durum Türk basın hayatında rekor olarak kabul edildi. Marko Paşa ilk sayısında "Maksadımız, sadece gülmek için gülmek değildir. Gülerek düşünmek ve faydalı olmaktır" 5 sözüne yer vererek amacını halka açıklamıştır.

Marko Paşa bir siyasi mizah gazetesi olarak yazılarında başbakan, bakanlar, milletvekilleri, valiler ve devlet kademelerinde yer alan şahısları konu edindiği için bu yönüyle de halk nazarında dikkat çekici bir hale gelmiştir. Marko Paşa'nın, yazılarında yer alan insanlarla dalga geçiyormuş gibi konuşması $^{6}$ ve halkın kullandığı dili tercih etmesi onun bir siyasi mizah gazetesinin gelebileceği en tepe noktaya ulaşmasına yol açmıştır.

Marko Paşa yazarlarının her biri dönemin zihinsel düşüncelerine oldukça hâkim olduklarından dolayı rahatça idareci-bürokrat konumuna gelebilecekken, bu yoldan gitmemeyi tercih etmişlerdir ${ }^{7}$. Marko Paşa

\footnotetext{
${ }^{5}$ Marko Paşa, 25 Kasım 1946.

${ }^{6}$ Marko Paşa, 9 Aralık 1946, 3. sayının manşetinde yer alan "R. Peker Markopaşayı ziyaret etti" bölümünde, dönemin başbakanı olan Recep Peker'in bir konuşma için gittiği yerde 2000 kişilik memur takımının sivil bir görüntü altında alkış göreviyle tutulduğu belirtilir. Bu konuşmadan sonra Recep Peker'in, Marko Paşa'ya ziyarette bulunduğu ve 7 Eylül kararlarının halka iyi geldiğine dair bir sohbete geçildiği ifade edilir.

${ }^{7}$ Levent Cantek, Markopaşa Bir Mizah ve Muhalefet Efsanesi, İletişim Yayınları, 2015, İstanbul, s.7.
} 
yazarlarının "toplumcu-gerçekçi" anlayışı benimsemesi, gazetedeki konuları ilginç hale getirmiştir. O zamana kadarki gazetelerde haber yapanlar, genellikle devletin lehine haber yapmışlardır. Bunun en önemli sebebi: "Bu yıllarda gazete sahiplerinin ve yazarlarının büyük çoğunluğu CHP milletvekili ya da bu partinin üyesidir. 1939 tarihli CHP Nizamnamesinin 160. maddesi bunlara parti çıkarlarına ve siyasetine uygun hükümetin uygulamaların kamuoyuna benimsettirici yayın yapmak ve bu çizgide olmayan yazı ve haberleri yasaklamak yükümlülüğünü getirmiş..." olmasıdır. Marko Paşa ile birlikte bu durum halkın lehine olmuştur. Gazetede yer alan haberler yüzünden Marko Paşa yazarları birçok defa tutuklanmış ve mahkûm edilmiştir. Gazete sahiplerinin hapse girmesiyle Marko Paşa kapanmış fakat daha sonra yeni bir adla yayın hayatına devam etmiştir. Marko Paşa' da yer alan yazıların imzasız olması nedeniyle gazeteye açılan davalarda birçok defa başyazar olarak gözüken Sabahattin Ali yargılanmıştır.

Gazetede işlenen konular genel olarak yabancı sermaye düşmanlığı, devlet yönetiminin halkla olan ilişkisini koparması, Atatürk inkılaplarının son bulması sayılabilir. Marko Paşa yabancı sermaye düşmanlığı konusunu, zamanında Türkiye' nin kapitülasyonları kaldırmak için çok uğraştığını şimdi ise aynı duruma düşmenin eşiğinde bulunulduğunu halka anlatmaya çalışmıştır'. Gazete, Kurtuluş Savaşı'nın yabancı sermayeyi Türkiye'den kovmak için gerçekleştiğini birçok defa kaleme almış, Türkiye'deki kötü yönetimin hâkim olmasını Atatürk'ün vefatıyla eş tutmuş, ${ }^{10}$ Atatürk'ten sonra gelen hükümetlerin yetersiz kaldığını çok açık bir şekilde vurgulamıştır. Atatürk'ten sonraki CHP yönetiminin halktan uzaklaştığını ve kendi ülkelerine yabancı kaldıkları, bunun sonucunda da halkın isteklerinin değil şahsi isteklerin ön plana çıtığ 1 da gazetenin dile getirdiği fikirlerdendirr ${ }^{11}$.

Marko Paşa, döneminin istenmeyeni olmuştur. O dönemde yayınlanan gazeteler genel itibariyle iktidar partisinin yürüttügü politikaların yanında yer almaktaydı. Bu nedenle muhalifliğe daha ilk sayısıyla giriş yapan Marko Paşa'ya karşı suçlamalar yöneltilmiş ve iftiralar atılmıştır. Yapılan suçlamalar genel olarak komünistlik boyutunda vuku bulmuştur. Marko Paşa'ya bu suçlamaları yönetenlerin tek taraflı olmadığı gözlemlenmektedir. Sabahattin Ali'nin 1944'ten beri Turanclarla iyi geçinememesi ${ }^{12}$, gazetede yer alan yazılarda şeriatçılık fikriyle özdeşleşen Necip Fazıl'la alay ediyormuş gibi

\footnotetext{
8 Barış Yetkin, "1945-1950 Arası "Demokratikleşme" Sürecinde Basın", 2012, Akdeniz Üniversitesi, İletişim Fakültesi, s.5.

${ }^{9}$ Marko Paşa, 2 Aralık 1946, "Yabancı sermaye" - Hür Marko Paşa, 30 Ağustos 1949, "Geçmiş zaman olur ki hayali metelik etmez".

${ }^{10}$ Medet, 3 Haziran 1950, "Sabık cumhurbaşkanı İnönü".

${ }^{11}$ Marko Paşa, 8 Şubat 1949, "Markopaşa dert dinliyor".

${ }^{12}$ Merhum Paşa, 26 Mayıs 1947, "Mahkeme Koridorlarında".
} 
görünmesi ${ }^{13}$ ve CHP yönetimine ağır eleştirileri sonucu ${ }^{14}$, Marko Paşa ortak düşman konumundayd.

Marko Paşa yüksek satış rakamlarına ulaşmasına rağmen bunu kolay bir şekilde gerçekleştirememiştir çünkü matbaa sahipleri muhalif bir gazete basmanın sorumluluğunu üstlenmek istemiyordu. Gerçekten de Marko Paşa'yı basan matbaa sahiplerine polisler gelerek gazeteyi basmanın sakıncalı olduğunu, ileride başlarına sorun yaratabileceğini söylemekteydiler. Yedi-Sekiz Paşa'nın 29 Nisan 1949 tarihli basımında polislerin herhangi bir evrak göstermeden 20.000 gazete toplatıldığı dile getirilmektedir ${ }^{15}$. Bu durum ekonomik açıdan da gazeteye maddi darbe vurmaktaydı çünkü matbaa sahipleri normal bir gazete baskısına oranla Marko Paşa'yı basmak için 3 kat daha fazla para istemekteydiler ${ }^{16}$.

Türk basın ve siyasi alanında muhalifliğin artmasına, güçlenmesine Marko Paşa'nın oldukça büyük etkileri olmuştur. Yayınlandığı dönemde birçok örneğin ilkini gerçekleştirmiştir. En çok basılan ve satılan gazete olmanın yanında birçok edebiyat eleştirmeninin kabul etmesiyle ${ }^{17} \mathrm{CHP}^{\prime}$ nin tek parti yönetimine, ilk karşı duran oluşum olarak yer almıştır. Marko Paşa aynı zamanda cumhuriyet tarihinde siyasi mizah türünde çıkan ilk gazete olma unvanina sahiptir ${ }^{18}$.

\section{Marko Paşa'nın Türk Halkına Anlattıkları}

Marko Paşa'nın yayınlandığı dönem içinde en çok vurgu yaptığı konu Amerikan yardımları olmuştur. Amerikalıların, Türkiye'ye sattığı malzemelerin iş göremeyecek kadar kötü ve eski olduğunu, I. Dünya Savaşı'ndan kalma bozuk aletler bulunduğu belirtilir ${ }^{19}$. Bu durama ek olarak Türkiye'ye verilen malların yalnızca Amerika'nın onaracağı, bakım yapacağı ve eksik malzemelerin Amerika' dan satın alınacağı konusunu gündeme taşımıştır.

Marko Paşa, iktidar yanlısı gazeteleri gerçekleri çarpıttı̆̆ı gerekçesiyle suçlamıştır. Türkiye'nin zor şartlar altında bulunduğu zamanlarda sanki her şeyin tozpembe gibi gösterilmesi karşısında Marko Paşa sessiz kalmamış, bu

\footnotetext{
${ }^{13}$ Marko Paşa, 2 Aralık 1946, "Mekke emirine havale".

${ }^{14}$ Marko Paşa, 24 Şubat 1947, "Gazete ve gazeteciler".

${ }^{15}$ Yedi-Sekiz Paşa, 29 Nisan 1949, "İki kamçı bir kuyruk herkes başına uyruk".

${ }^{16}$ Marko Paşa, 10 Şubat 1947, "Islaha çalışırken” - Malûm Paşa, 8 Eylül 1947, “Bir gazete çıktı”.

${ }^{17}$ Asım Bezirci, Rıfat Ilgaz, Çınar Yayınları, 1992. İstanbul, S.9.

${ }_{18}$ Mehmet Saydur, Markopaşa Gerçeği, Çınar Yayınları, 2013, İstanbul, s.26. - Kitapta bahsi geçen cümle şöyledir: "Zekeriya Sertel'in de belirttiği gibi, Markopaşa siyasal mizah türünde çıkan ilk gazetedir".

${ }^{19}$ Malûm Paşa, a.g.e., "Şehir ve yurt haberleri" - Bu bölümde Amerika'nın Türkiye'ye "yardım" için vereceği 10 gemi adına 7 milyon 400 bin, tamir için de 6 milyon lira verileceği vurgulanır.
} 
haberleri yapan gazetelerle mücadele işine girmekten korkmamıştır ${ }^{20}$. Aziz Nesin "Krallar İşi Azıttılar" adlı yazısı için şunları söylemiştir: "İngiltere, Iran ve Misır devlet başkanlarının Türkiye'deki büyükelçilikleri aracılığıyla aleyhime dava açmalarına ve Iran Şahı ile Mısır Kralı'na hakaret sayılarak üçer aydan altı ay hapis yatmama neden olan bu yazıyı yazmamın amacl, Türk halkının büyük ekonomik sıkıntılar içinde bulunduğu o günlerde basınımız sürekli olarak bu üç devlet başkanının evlenmeleri, boşanmaları, çocuk yapmalarıyla uğraşarak kamuyu boş yere oyalamaların eleştirmekti"21.

Marko Paşa'nın en çok eleştirdiği konulardan birisi de 7 Eylül kararlarıdır. 7 Eylül kararları cumhuriyet tarihinin ilk devalüasyon hareketidir ${ }^{22}$. 7 Eylül 1946 tarihinde açıklanan bu kararla beraber piyasada bulunan ürünler geri çekildiği için karaborsaya düşmüştür. Piyasada kalan ürünlerin fiyatları ise oldukça pahalılaşmıştır. Hükümet, bu vahim durum karşısında vergileri yükseltmeyi çözüm olarak görmüşse de bu durum halkı çok daha zor bir hale getirmekten öteye gidememiştir. Alibaba'da yayınlanan "Bizi sevmiyorlar"23 adlı yazıda hükümetin 7 Eylül kararlarını kendi çıkarları için aldığı, halkın perişan duruma düşmesinin umurlarında olmadıkları belirtilmiştir.

Gazetenin popüler hale gelmesinden sonra en önemli sorunu hükümet kararıyla toplatılmış olmasıdır. Türk halkının Marko Paşa'yı sevmesi esasen iktidar partisi CHP'nin hoşuna gitmiyordu. Hükümetin bu gazeteye olan teveccühe bulduğu çare ise gazetenin daha yayınlandığı gün toplattırılması şeklinde olmuyordu. Marko Paşa bir mizah gazetesi olarak yasaklamasına yine bir mizah gazetesi sınırları içerisinde kalarak mizahi bir yorum yapmaktan geri kalmıyor, gazetenin başlığının altında yer bulan: "Ne gün firsat bulursa o gün çıkar. Çıktı̆̆ı gün 8 ile 9 arası satılır. 9 da toplanmaya başlarlar" yazısıyla akıllardan silinmeyecek olan cevabı veriyordu. Ayrıca "Toplatılmadı̆̆g zamanlarda çıkar", "Fırsat bulabildiği zamanlarda çıkar", "Ankara ve Samsundan başka dünyanın her yerinde satılır" gibi sözler de bu mizah anlayışı içinde ifade edilmiştir.

Marko Paşa'nın üstünde hassasiyetle durduğu konulardan bir tanesi de hastalık meselesidir. Türkiye'de yaşayan insanların büyük çoğunluğunda verem, trahom, frengi, sıtma gibi hastalıkların bulunduğunu, bu durumun

20 Marko Paşa, 9 Aralık 1946, “İşte bütün mallar meydanda” - Bu bölümde Marko Paşa, Malatya'da yayınlanan yerel gazetelerin yalan haber olduğunu okuyucu mektuplariyla açıklamıştır. Malatya Valisi ile tekzip vasıtasıyla diyaloğa girerek, kötü durumu halka göstermeye çalışmış, Malatya Valisi ise durumun tam tersi olduğunu Marko Paşa'ya aktarmıştır.

${ }^{21}$ Aziz Nesin, Geriye Kalan, Nesin Yayınevi, 2019, İstanbul, s.71.

22 Sema Kahraman Vurucu, Türkiye'nin Değişim Yıllarnnda Siyasi Mizahla Muhalefet Örneği: Marko Paşa Gazetesi, İstanbul, 2013, s.29.

${ }^{23}$ Alibaba, 9 Aralık 1947, "Bizi sevmiyorlar". 
bilindiği halde hastalıkla mücadele kapsamında yeterli adımların atılmadığını anlatmaktadır. Sağlık personeli bakımından da oldukça yetersiz kalındığı, birkaç kasabaya ancak bir doktor düştüğü bilgisi de bu paylaşımlar arasında siklıkla yer bulmuştur ${ }^{24}$.

Marko Paşa yayınlandığı dönem itibariyle eleştirilerini daha çok iktidar partisi üzerinde toplamıştır. CHP'nin yönetiminde yer alan insanların, Türkiye'ye karşı sorumluluklarını yerine getirmedikleri gibi sadece kendilerini düşünen bir kurum haline dönüştüğünü anlatan cümleler gazetenin haberleri arasında yer almıştır ${ }^{25}$. Marko Paşa'nın bu muhalif kişiliği sadece CHP'ye yönelik değildir. DP'nin sürekli olarak piyango, çekiliş, kokteyli eğlence, ziyafetler vererek olumlu imaj çizmediğini ${ }^{26}$ ifade etmekten de geri kalmamıştır. Marko Paşa, DP ve CHP dişındaki az ilgi gören partilere çok fazla değinmese bile bu partiler hakkında da zaman zaman haberlere yer vermiş ve demokrasiye adım atmaları yönünde düşünceler sarf etmiştir.

Marko Paşa'nın Türk halkına anlatmak istediği bir konu da af meselesidir. Fransa, Yunanistan, İtalya, İran ve İspanya'da birçok defa af yasasının kabul edildiğini fakat Türkiye'nin 1933 senesinden beri bu durumu gerçekleştirmediği vurgulanmıştır. Türk halkının af konusunu dört gözle hükümetten beklediği gazetede sik sık tekrarlanmıştır. $\mathrm{Bu}$ af konusunun gazetede sık sık tekrarlanmasının bir başka nedeni de Aziz Nesin ve Rıfat Ilgaz'a ait temyiz edilmiş davaların bulunmasıydı. Bu sebeple denilebilir ki yazarlar kendilerini de düşünerek af haberlerine yoğun ilgi göstermişlerdir.

Marko Paşa'nın af konusu gibi üstünde sıklıkla durduğu bir diğer olay ise Nazım Hikmet'in tutukluluk halidir. Bu konu hakkında çok fazla durulmasının ve yazılar kaleme alınmasının en büyük gerekçesi, Nazım Hikmet'e anayasada yer alan herhangi bir maddeye dayanmaksızın cezai işlem uygulanmasıdır ${ }^{27}$. Bu olay Marko Paşa'nın 3. döneminde neredeyse her sayısında el alınan bir konu olmuştur.

\section{Marko Paşa Yazarlarının Suç Unsuru Sayılan Yazıları}

4 Aralık 1946 tarihinde Cemil Sait Barlas'ın TBMM'de yaptığ konuşmasının bir bölümü aşağıda aynen verildiği gibidir:

“Gazeteler çeşit çeşit müdahalelerde bulundular, İstanbul'da değil şu ve bu partiye mensup gazeteler hatta kökü dışarda olan Markopaşa bile çıkıyor. Ve bu gazete çıktığı zaman Sıkıyönetim kumandanı haklı olarak dış

\footnotetext{
${ }^{24}$ Hür Marko Paşa (Yeni Seri), 15 Mayıs 1950, "O kadar uzun boylu değil”.

${ }^{25}$ Marko Paşa, 17 Şubat 1947, "Halil İbrahim bereketi”.

${ }^{26}$ Malûm Paşa, a.g.e., "Allah afiyet versin".

${ }^{27}$ Hür Marko Paşa (Yeni Seri), 8 Mayıs 1950, "Büyük şair Nazım Hikmet'in hayatı tehlikede" Hür Marko Paşa (Yeni Seri), 15 Mayıs 1950, "Günah olan nedir?".
} 
tehlike için ilân edilmiş olan Sıkıyönetimi hüsnü idare ederek bunun için tatbik edilecek muameleyi Cumhuriyet Savcılığına bırakıyor. Bu da ayrıca şayanı şükrandır. Şu halde diş tehlike için ilân edilmiş olan ve ancak bazı yerlerde seysefer hürriyetini, bazı şartlar altında ve sirf memleketin müdafaası bakımından tatbik etmektedir. Sayın Köprülü arkadaşımın, arzettiğim gibi kökü dışarıda olan ideolojiler için, nasıl bizimle beraber iseler, Sikıyönetimin ilânında da Partisinin bizimle beraber olduğunu bu kürsüden söylesinler. Bunu yapmadı. Bu bakımdan arkadaşlar, sırf dış tehlike için ve hudutlarımızı yalazlıyan tehlike ve ihtilâl hareketleri için ve mevzuubahsolan isyanlar için ve mevzuubahis notanın mevzuu olan mıntakalar için ilân edilmiş Sıkıyönetimin şimdiye kadar olduğu tarzda ve iç işlerde Cumhuriyet normal kanuni arına birakarak temdidini rica ediyorum"28.

Cemil Sait Barlas'ın bu konuşması üzerine Marko Paşa'nın ilk defa şikâyet edilmesine de vesile olacak olan 4. sayısında "Topunuzun Köküne Kibrit Suyu" başlıklı bir yazıya yer verilir. Bu yazı şöyledir:

"Milletvekili Cemil Barlasa pulsuz mektup

Sayın demeye dilim varmyor sana. Yabanct ideoloji diye bir garibe icat eylediniz. Bütün dünya size pabuçlarn ile güldü. Bugün sayenizde maskaraya dönen demokrasiyi, acaba bey pederiniz mi icat etmişti?

Yabancı sermayeye, kapıları ardına kadar açarak kul köle oldunuz. Fikre ve ilme gümrük duvarları çektiniz. Bu marifetiniz yetişmiyormuş gibi, şimdi de bir kök tutturmuşsunuz: kökü dışarda, kökü içerde, kökü havada ve sizin kökü suda. Çok muzip adamsin vesselam. Nereden de bulursun bu acaiplikleri?

Şu kalemi tutan ellerim dünya yüzeyinde hiç bir şey yapamamış bile olsa, seçimde sana rey pusulası atmadiğı için, en mukaddes vazifesini yapmış sayılır.

Neden bizim kökümüz dışarda? Biz hürriyetin yüzüne çul mu örttük? Biz cebimizde firar pasaportları ve sahte nüfus kă̆gtları mı taşıyoruz? Cüzdanlarımızda yabancı bankaların hesap defterleri mi var?

Ellerim mesuttur, Cemil Barlas sana rey vermediler.

Neden bizim kökümüz dışarda? Tapuları karılarımızın üzerine yapılmış apartmanlarımız mi var? Biz bu millete uşaklarımızla, bendeganımızla, dalkavuklarımızla, metreslerimizle mi bağlıyız? Biz bu vatana apartmanlarımızın oturduğu toprak parçası ile mi bağlıyız?

${ }_{28}$ TBMM Tutanak Dergisi, 4 Aralık 1946, 8. Dönem, Cilt:8, s.18. 
Ellerim bahtiyar Cemil Barlas sana rey vermediler.

Biz misalini dahi gördüğ̈̈müz ve her gün kulağımıza bir haberi uçurulan dayak, yağma, talan, ölüm, zindan ve sürgün pahasına da olsa milletin menfaatine olan hakikatleri söyleyeceğiz. Bunun için mi kökümüz dişarda?

Ellerim huzur içinde Cemil Barlas, sana rey vermediler.

Sizden her zaman daha kolay elde edebileceğimiz refahı teptiğimiz için, lütfedilen sandalyeleri kafalarında parçalayacă̆ımız, tavsiye edilen menfaat ve rütbeleri suratlarına fırlatacă̆ımız için mi kökümüz dışarda?

Teşrii masuniyetin arkasına gizlenip, size taş atmadiğımız halde üzerimize sıçratmak istediğiniz iftiralarmı beyhudedir. Millet verdiğiniz afyonlara da muafiyet kesbetti, yutmuyor artık.

Bizim ne teşrii, hatta sayenizde ne de gayri teşrii masuniyetimiz var.

Bütün gayretlerinize rağmen millet, kökü kurtlu olanları da, çürük olanları da, köksüz olanları da biliyor.

Ellerim rahattır Cemil Barlas, sana oy vermediler.

Bir şeycikler demem vatan, millet, namus gibi mukaddes kelimelerin, manalarıyla değil, yalnız lafizlarıla milleti en hassa yerinden avlamak arzusu ile keselerini ve menfaatlerini köle yapmak isteyen ve bize kökü dışarda diyenlerin kökleri kurusun, topunuzun köküne kibrit suyu!

Ellerim bahtiyar

Ellerim ve sen Cemil Barlas!" 29

Bu yazı sonrasında Cemil Sait Barlas'a hakaret gerekçesiyle gazeteye dava açılır. Yazıyı Aziz Nesin yazmasına rağmen gazetedeki haberlerin imzasız olması dolayısıyla mahkemeye çıkan şahıs Sabahattin Ali olmuştur. Sabahattin Ali, dava sonucunda 4 ay hapis ile 66 lira 60 kuruş para cezasına çarptırılmıştır. $\mathrm{Bu}$ yargilama sonucunda gazetenin kurucusu olan Sabahattin Ali hapse atılan ilk yazarolmuştur.

Yaşanan bu olaydan sonra 9. sayıda yayınlanan "Alibaba ve Kırk Haramiler" başlı̆̆ı ikinci suç unsuru oluşturan yazı olmuştur. Bu başlık altında yazılan metin tamamen kara mizahtır ve halkı güldürmeye yönelik bir amaç taşımaktadır. Sabahattin Ali'ye matbuat kanunun 30. maddesine ${ }^{30}$ dayanarak dava açılmış, yargılama sonunda Sabahattin Ali suçsuz bulunmuştur.

\footnotetext{
${ }^{29}$ Marko Paşa, 16 Aralık 1946.

30 T.C. Resmi gazete, 8 Ağustos 1931, 30. Madde: Türk ceza kanununun 156'inc1 maddesi sarahati haricinde kendilerine mevdu vazifenin ifasından dolayı Büyük Millet Meclisi
} 
Marko Paşa'ya atfedilen diğer suç unsuru, 14. sayıda yayınlanan "Markopaşa Ansiklopedisi" başlıklı yazıdır. Bu yazı maddeler halindedir. Yazının tamamı şöyledir:

"Biliyor musunuz?

- Necip Fazılis CHP'nin piyes müsabakasinı kazandığı halde, partinin oyun bozanlık ettiğini biliyor musunuz?

- Karikatürist Ramiz Gökçe'nin ${ }^{32}$ on beş senedir kırk yaşında olduğunu biliyor musunuz?

- Mutad şımarıklık, sırnaşıklık ve sululukta devam ederse, Doğan Nadi'nin ${ }^{33}$ iki seneye varmadan, mayi haline geleceğini biliyor musunuz?

- Falih Rıfkı'nın ${ }^{34}$ apartmanlardan aldığı hava parasile ve zaruret içinde geçindiğini biliyor musunuz?

- Ingiltere, açız diye bağırdı̆̆ı halde Şalcı Nihat Erim'in ${ }^{35}$, ille toksunuz diye ayak dirediğini biliyor musunuz?

- Markopaşa'nın 13 sayıda 24 matbaa değiştirdiğini biliyor musunuz?

- Büyük Müslüman ve İslam âlimi, Ömer Rıza Doğrul'un³ şaribülleyli vennehar ${ }^{37}$ olduğunu biliyor musunuz?

- Millet mecmuasinda din propagandasi yapan Cemal Kutay'ın ${ }^{38}$ bir başkasının arkasına gizlenerek, "Çapkın" adlı çırılçıplak ve anadan doğma mecmua çıkardı̆̆ııı biliyor musunuz?"39

\footnotetext{
Âzasından, icra Vekilleri Heyetinden ve resmî heyetlerle Devlet memurlarından biri veya bir kaçı halikında isim ve madde gösterilmeyerek müphem ve suizannı davet edecek mahiyette mütecavizine yazı ve resimlerle Büyük Millet Meclisinin ve İcra Vekilleri Heyetinin ve resmî heyetlerle Devlet memurlarının veya bir kısmının şeref ve haysiyeti ihlâl olunursa üç aydan altı aya kadar hapis ve yüz liradan eksik olmamak üzere ağır para cezası hükmolunur.

${ }^{31}$ Şair, romancı, oyun yazarı, gazeteci. 8 Eylül ile 16 Aralık 1947 arası kendisine ait olan Büyük doğu matbaasında Marko Paşa gazetesini basmıştır.

32 Karikatürist. Birçok gazetede resimleri yer almıştır. 1947'de "Salon" adında bir dergi çıkarmıştır.

${ }^{33}$ Gazeteci. Gazeteci olan babası Yunus Nadi'nin yanında Cumhuriyet ve Tasvir gazetelerinde çalışmıştır.

${ }^{34}$ Gazeteci, milletvekili. Ulus gazetesinin başyazarı ve 1935-1950 arası CHP Ankara milletvekili.

35 1943-1950 arası CHP Kocaeli milletvekili, Bayındırlık Bakanlığı ve başbakan yardımcılığı görevlerini üstlenmiştir.

${ }^{36}$ Mısır doğumludur. Türkçe Çevirmenliği, muhabirlik, yazarlık ve öğretmenlik yapmıştır. 1947-1948 arası hem Cumhuriyet hem de "Selamet Mecmuası" adlı gazetelerde çalışmıştır.

${ }^{37}$ Şemseddin Sami, Kâmûs-ı Türk̂̂, Çağrı Yayınları, 2014, İstanbul s.763., şaribülleyli vennehar = gece gündüz içen, işrete müptela.

38 Gazeteci. Anadolu Ajansında muhabirlik yaptıktan sonra Ulus gazetesinde çalışmaya başlamıştır. Sonraki yıllarda Millet ve "Hakka Doğru" gazetelerinde çalışmıştır.

${ }^{39}$ Marko Paşa, 10 Mart 1947.
} 
Aslında yazıda birçok kişinin adı zikredilmesine rağmen sadece Falih Rıfkı Atay dava açmıştır ve bu konuyu şöyle dillendirmiştir: "Bir Türk vatandaşının apartman veya apartmanları olması ayıp değildir. Fakat benim hiçbir apartmanım, gelir getirici hiçbir mülküm yoktur" ${ }^{\prime 4}$. Gazetenin sahibi olarak gözüken Sabahattin Ali mahkemede bulunmuş, yargılama sonucunda Sabahattin Ali, 3 ay hapis, 1000 lira tazminat ile 100 lira para cezasina çarptırılmıştır.

Marko Paşa'nın kapanmasına neden olan metin bir eleştiri yazısından değil, bir şiir yüzünden kaynaklanmıştır. 19. sayıda yayınlanan "Dediğin" adlı şiir "hükümetin manevi şahsiyetini tahkir" olarak değerlendirilmiştir. Dediğin adlı şiir şöyledir:

“Dediğin

$$
\text { Muallim Naci'ye }{ }^{41} \text { nazire }
$$

Şunlarm dâmenine yüz mü sürer er dediğin

Öptürür dâmenini kavmi gazanfer dediğgin

Senin ey milleti merhume değişmiş lügatin

Eyi teşhise çalış, kargadır önder dediğin

(İttihad) ında aşındırmış idin dâmenini

Ne atâ (!) etti, bilirsin (Enver) dediğin.

Ayn cinsten ve o maldan bu bakayayı züyuf

Bir çakıl parçasıdır sehv ile cevher dediğin.

Kokladım -misk diye- yıllarca o kokmuş eteğini

Böyle murdar mı kokar hep, senin anber dediğin

Bak şu insan diye bildiklerinin yüzlerine

Ona nispetle asaletlidir ester dediğin

\footnotetext{
${ }^{40}$ Cumhuriyet, 13 Mart 1947.

${ }^{41}$ Aruz veznini kullanan Tanzimat dönemi yazarlarındandır. "Lugat-i Nâci" adlı Osmanlıca sözlük eseri bulunmaktadır fakat bu eser kendisinin ölümünden sonra tamamlanmıştır.
} 
Öyle alûde ki: Çirkab ile esnamı zaman

Silemez bunlar bir hamlede sünger dediğin

Düşme bir parça zamanin nazarından hazer et

En büyük düşman olur dünkü birader dediğin

Markopaşa bunu öğrendi, fakat bade harap...

Yol kesen çıkmadadır hasıl rehber dediğin.

Lügat:

Dâmen-etek, atâ-vermek, sehv-yanlışlik, alüde-bulaşık, esnamı zaman-zamanın put diye tapinanları, hazer et-kork, bade harap-iş işten geçtikten sonra." ${ }^{42}$

Sabahattin Ali, başındaki davalar yüzünden gazeteyi Mücap Ofluoğlu'na devretmiştir. Marko Paşa'nın 15, 16 ve 17. sayılarında sahip olarak gözüken Mücap Ofluoğlu, bu üç sayıdan sonra Marko Paşa'yı karikatürist Mustafa Uykusuz'a emanet etmiştir. Mustafa Uykusuz'un sahipliği altında 19. sayıda yayınlanan şiir dolayısıyla hakkında dava açılmış, şiiri kimin yazdığı mahkeme tarafından belirlenen süre içinde söylenmediğinden 22. sayı ile beraber Marko Paşa kapatılmıştır.

Marko Paşa 22. sayısını yayınladıktan hemen 1 hafta sonra tıpkı aynı gazete çıkıormuşçasına, Sabahattin Ali sahipliğinde "Merhumpaşa" adlı gazete yayınlanmaya başlanmışııı. Merhum Paşa'nın ilk sayısında yayınlanan "Mahkeme Koridorlarında", "Irkçı Dalaşması" ve "Genç Arkadaş" gibi yazılar yüzünden yeni davalar açılmıştır. İsmet Rasin Tümtürk "Mahkeme Koridorlarında" adlı yazıya dava açarken, Nihal Atsız hem aynı yazıya hem de diğer iki yazıya karşı mahkemeye başvurmuştur. Bu başlıklardan "Mahkeme Koridorlarında" adlı yazının tamamı şöyledir:

"Hasan Âli-Kenan Döner Komedisi

Hasan Âli-Kenan Döner komedisinin dünkü temsilinde, Hitlerin acemi çırakları gülünçlü nutuklarına devam etmişlerdir. Nihal Atsız gezici kumpanyasını seyre gelenler salonu tıka basa doldurmuşlardı.

42 Marko Paşa, 28 Nisan 1947. 
Evvelâ Kenan Döner kantoya çıktı:

"Oğlan döne, kız döne. Geldim ben döne döne" şarkısını döne döne söylerken, evvelâ gözü döndü, sonra başı döndü, nihayet nevri dönüp, ihtiyar dansör, kumpanya aktörlerinin alkışları arasında yere yuvarland.

Ikinci perdede yine Kenan Döner çıtı. Göbek boşluğuna Nihal Atsız yerleşmiş bulunuyordu. İhtiyar Döner ă̆zını açar açmaz ă̆ızından adsız Nihalin kafası firlamış ve "Hayl Hitler!" diye üç defa horladıktan sonra; Hasan Âlinin Milli Ĕğitim Bakanlı̆̆ında Staline, Molotofa iş verdiğine dair tiradına başlamıştır. Nutkun sonunda "Hasan Âli bir komünisttir demiş", sebebi sorulunca:

- Çünkü faşist değildir, diye cevap vermiştir.

Bundan sonra Arnavut oğlu Arnavut olup, kendisi Türk oğlu Türk, büyük ırkçı ve Türkçü İsmet Rasin de Hasan Âlinin komünistliğine şahit etmiş ve ispat için de, halis kan soyunun, yarım kan ırkının üstüne yemin billâh edince akar sular durmuştur.

Tanık, sanık ve diğer faşist artıklarının numaraları başka güne kalmıştır." 43

İsmet Rasin Tümtürk tarafından açılan dava sonucu Sabahattin Ali 3 ay hapis cezasına çarptırılacak, böylece yeni açılan Merhum Paşa ilk sayısıyla sahipsiz kalacak ve gazete geçici süreliğine kapatılacaktır. Nihal Atsı'ın dava ettiği diğer kaleme alınan "Irkçı dalaşması" başlıklı yazı ise şöyledir:

[Irkçıların kâhküllü führeri, âdeti oldŭ̆u üzere mühim adam tavırları takını ortaya bir balgam daha atmış: "komünistlerin asıl şeflerinin kim olduğunu biliyoruz, ama iki seneden önce söyleyemeyiz!" demiş. Başka bir ırkçı derginin başyazarı bir bayan da soruyor: "Bu asıl şefler kimlerdir? Bunlarn isimlerini saklamak, komünistleri himaye etmek demektir!"

Gördünüz mü, bu zavallıların silâhları ne kadar çabuk kendilerine çevriliyor? Bir Fransız atasözünü değişstirerek şöyle diyebiliriz:

"Bir faşist, her zaman kendisine komünist diyecek daha azılı bir faşist bulabilir." $]^{44}$

Merhum Paşa'da hakkında dava açılan üçüncü yazı “Genç Arkadaş” adlı metindir. Bu metnin içeriği şöyledir:

\footnotetext{
${ }^{43}$ Merhum Paşa, 26 Mayıs 1947.

${ }^{44}$ Merhum Paşa, a.g.e.
} 
"Yurdunu, milletini her şeyin üstünde tut. Bütün varlı̆̆ın bu topraklarn şenlendirmek bu topraklar üzerinde yaşayan insanlarn yüzünü güldürmek yolunda harca.

Birbirini boğazlamadan yaşamak istiyen bütün insanlara dostluk göster; kendi menfaatleri için dünyayı kana bulamak istiyenlere inanma. Bunları insanlı̆̆ın, yurdunun ve milletinin düşmanı say.

Yurduna açık veya gizli yollardan girmek ve yerleşmek isteyen yabancilara yüz verme. Seni sömürmek ve köle etmek istiyen böyle düşmanlara karşı kafanla, kaleminle, gerekirse kanınla mücadele et.

Bu millete dayanmadıkları için, her halde yabancı bir devlete dayanmak lâzım olduğunu seni inandırmak istiyenlerin sözüne kanma.

Müdafaa edilecek fikirleri olmadığı için her türlü fikre düşmanlık edenleri ve etraflarna sadece kabiliyetsiz, cahil sürüler toplamak istiyenleri arana sokma.

Seni maceralara sürüklemek isteyen gafillere yüz verme. Bu milletin bin bir yarasına merhem olmayı bir yana bırakıp dipsiz maceralar peşinde, yabancı ülkeleri zaptetmek hülyalarile halkı kırdırmak, bu arada külah kapmak isteyen vicdansızların parlak sözlerine kulak asma. Çünkü sen, büyüklük delisi zevzeklerin, Hitler kâhküllü kaçıkların oyuncă̆̆ olamıyacak kadar ă̆ır başlısın.

Ve hele her şeyin başında, seni aldatarak alçakça işlere oyuncak etmek istiyen düşmanınla, sana hakikati söyliyen dostunu birbirinden ayırması bil! Bunu senin zekândan ve namusundan bekleriz." 45

Nihal Atsız tarafından açılan bu davalar sonucu Merhum Paşa'nın sahibi Sabahattin Ali herhangi bir ceza almamış lakin İsmet Rasin Tümtürk tarafından açılan dava sonucunda Merhum Paşa'nın 1. sayısıyla beraber geçici olmak üzere kapanmasına neden olmuştur.

Merhum Paşa'nın başından geçen bu olay neticesinde yaklaşık 4 ay boyunca gazete çıkarılamamış, Eylül 1947'de "Malûmpaşa" adıyla yayınlanmaya başlanmıştır. Malûm Paşa'nın 15 Eylül'de yayınladığı 2. sayısında "Mahkeme Koridorlarında" başlıklı yazı, "adalete tahkir" gerekçesiyle gazete hakkında dava açılmasına sebep olmuştur. Davaya neden olan yazı şöyledir:

\section{“Gün Ŭ̆ursuzun}

Sakin duruyor, suçlu o değilmiş gibi:

${ }^{45}$ Merhum Paşa, a.g.e. 
- Suçun ne? diye sordular.

Göğsünü kabartıp, bir matah yapmış gibi:

- Siyasi! dedi.

Bu kendi halinde siyasi suçludan lâf almak ta zordu. Sonra nasılsa çenesi açıldı, bülbül gibi anlativerdi:

O "gece işi" yaparmış, yani gece hırsızı. Ara sıra üzüntülü bir hal aldığı oluyordu. Sorulardan bir hisse çıkarmış olacak ki, birden:

- Benim teselliye ihtiyacrm yok, dedi. Siyasi suçu olan, öyle bir adamdır ki, bugün kıçına tekme vurup rezil edileni yarın salla sırt edilip, omuzlarda, sırtlarda taşınır. Bugün misallerini görüyorsunuz. Dün dut yemiş bülbül gibi susanlar, bugün luca bülbülü gibi ötmüyorlar mı? Hayat bu, efendim. Benim kadrimi bilmediler, siyasi suçtan dolayı beni huzura çıkarmadılar. Amma, yarı görürsünüz. Halkın sırtına binip, alkışlar arasında nutuk vereceğim

Kendinden o kadar emin konuşuyordu ki, benim de, herkes gibi onun sahiden siyasi suçlu olacă̆ına inanacağım geldi. Acaba hırsızlı̆̆ı, sırtta nutuk vermeği ve siyaseti birbirine mi karıştırıyordu? Biraz daha zorlanınca, alçak sesle ve bir sir söyler gibi:

- Efendim, Tophane güllelerini cebime doldurdum darldir diye. Sultanahmet minarelerini belime soktum borudur diye, tutmasmlar mo beni delidir diye! Bereket versin Hacı Canbaza: bana bir beygir verdi dorudur diye, beygiri ahıra bağladım karıdır diye, beygir bana çifte atmasın mı geri dur diye!

Zavall adam. Hepimiz acıdık. Aklını oynatmıs bu zavall bana sonsuz bir üzüntü verdi. Bununla beraber kendisine hak verdim. Halkın sirtına binmek için bütün şartları tekmillemiş. Bununla beraber siyasi hayat bu, belli olmaz. Yarınından ümmitli olduğum için, bu adamı alkışlamak, sırtımda taşımak arzusu içimden geldi: sırtıma binsin, nutuklar versin, sitajını yapsın. Bir baltaya sap olacağım yok! Bari, bu gece kuşu, zırdeli siyasi suçluyu, bel bağlayayım.

Malûm ya, gün uğursuzun." ${ }^{46}$

Davada hapisten yeni çıan Sabahattin Ali hazır bulunmuştur. Sabahattin Ali mahkemede tutuksuz olarak yargılanmıştır. Bu dava Marko Paşa'nın 1. dönemi olarak ifade edilen zaman aralığında açılan son dava olmuştur. 1. dönemin sonunda Sabahattin Ali gazete sahipliği görevini

46 Malûm Paşa, 15 Eylül 1947. 
bırakmıştır. İkinci döneminde Rıfat Ilgaz artık gazetenin sahibi konumunda olacaktır.

Tekrar Marko Paşa adıyla yayınlanan 2. dönemde, yargılanmaya yol açan 5. sayıda yer alan "Pamuk Prenses Elizabet doğurdu" ve "Dünya kralları işi azıttılar" başlıklı yazılardır. "Pamuk Prenses Elizabet doğurdu" yazısı şöyledir:

"(Ankara radyosunun hırıltı, dırıltı ve gürültüsü arasından güçbela duyulmuştur)- Üstünde güneş batmayan, fakat müstemleke insanları batan şahane Ingiltere imparatorluğunun nazenin pamuk Prensesi Elizabet, Eminönü meydan saati ayarile dün gece saat üçü on bir buçuk dakika, dört saniye geçe doğmuştur.

Krali yumuryacă̆ın haşmetli valdesinden hurucu esnasinda, İngilterenin İçişleri Bakanı dünya kapısında, Dışişleri Bakanı da dış kapıda nöbetler tutuyorlard.

Doğum münasebetile, yol gitmez, kuş uçmaz, kervan geçmez, doktor bilmez, Bakan uğramaz köylerimizde davullar, zurnalar çalınacak, ricali umur ve ehli kuburun da etekleri zil çalacaktır. Şahane kral kurusuna şimdiden dalkavukluk için \{okunamadı- muhtemelen icap olabilir\} edenlere emir verilmiştir.

Prensesle prensin ilk randevularından tam dokuz ay, dokuz gün, dokuz saat, dokuz dakika, dokuz saniye sonra dünyaya gelmesi de Ingilizlerin ne kadar sözünün eri oldukların bir kere daha ispat etmiştir.

Yaşasin kral kurusu!" 47

Aynı sayıda yayınlanan "Dünya kralları işi azıttılar" yazısı ise aynen şöyledir:

"Son günlerde dikkat ettiniz mi, Krallara ve Kraliçelere bir azgınlık arız oldu. Kimi evleniyor, kimi boşanıyor, kimi doğuruyor... biz de dünyaya demokrasi gelecek diye, ha babam avucumuzu yalyoruz

Bir zamanlar İran Şahı evlenecek oldu. Sanki el malile gerdeğe biz girecekmişiz gibi düğün bayram ettik. Zavallı Türk halkı, bir Pazar olsun seyrana gidemezken İran Şahının düğ̈̈nüne giranbaha hediyeler gönderdik, gazeteciler, muharrirler, bölük bölük askerler gönderdik. Sözüm ona biz Cumhuriyetiz de, hani Iran da Krallik.

Ne oldu, ne bitti bilmeyiz, Iran Şahının karısı, Mısır Kralının da kardeşi güzel Fevziyecik, Şahın burnunu mu beğenmedi, her ne oldu ise, kocasına Dıran Dedenin düdüğ̈̈ gibi, Şahlık âsası elinde sipsivri Tahran

${ }^{47}$ Marko Paşa, 26 Kasım 1948. 
sarayında bırakıp, ă̆abeyisi Mısır Kralının yanına kaçtı. Şimdi öğrendik ki boşanmışlar. Biz Cumhuriyetiz, bize ne değil mi? Yooo... Bizimkilerde bir ahi figan, gazetelerimiz, radyomuz iki gözü iki çeşme kan ă̆lıyor.

Derken arkadan Kral Faruk da, galiba Iran Şahını kıskanmış, o da karısı Prenses Ferideyi boşamışmıs. Resimlerine bakılırsa, hani Feride de Feride...

Nasıl kıydı bilmem? Sebep olarak ta Feride'nin hep kız

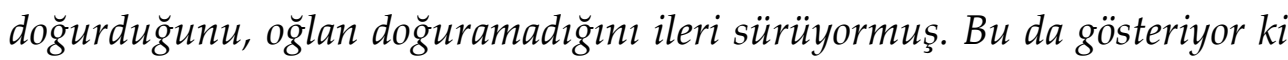
Kralların gözünde kadın, hala kuluçka makinasinden başka bir mal değildir. Bizim köyde erkek evlâdı da, kız evlâdı da yapan erkektir.

Kral Faruk geniş bir araziyi, paha biçilmez mücevheratı, muazzam malları hep Prenses Ferideye bağışlamış. Bă̆ışlar a... Bu malı mülkü kazma sallayıp, kafa patlatıp kazanmadı ya. Bu yeni zevce erkek doğurursa ne âlâ, doğurmazsa yallah... Ona beş on çiftlik, haydi yenisi. Amasyanın bardă̆g, bir olmazsa bir daha... Misırda arazi mi yok, mücevher mi yok, çiftlik mi yok, yoksa karı mı yok... Zavallı Misır fellahının da Nil bataklıkları içinde iki hurma çekirdeğine anası ă̆lasın dursun. Bir yandan haşmetli Misır Kralını, bir yandan daha haşmetli Ingiliz imparatorunu beslesin.

Biz Cumhuriyetiz, Misır Kralından bize ne değil mi? Yooo... baksanıza gazetelerimiz, radyomuz, ajansımız iki gözü iki çeşme ă̆lıyorlar. Mısır Kralı, İan Şahını kıskanıp karıyı boşadı. Şimdi ister misiniz, Türkiye Cumhuriyeti Krallı̆̆ının da prensleri öbür krallara özenip te karlların dehlesinler. Sen o zaman gör curcunayı, mahkemeler boşanma dâvasindan adam almaz. Çünkü Mısırda, İranda kral bir tane, halbuki bizde şahlar, şahbazlar, krallardan geçilmiyor. Şefler, şeflerin kuyruğu, kuyruğunun kuyruğu, şeker kralları, pirinç kralları, zeytinyă̆ kralları, hepsi de küçük dağları ben, büyüklerini de o yarattı diyor.

Vallahi bu günlerde krallar azdı, başlarına galiba bir gelecek var." 48

"Pamuk Prenses Elizabet doğurdu" ve "Dünya kralları işi azıttılar" yazılarından dolayı İngiltere, İran ve Mısır devletleri Türk dişişleri yetkililerine başvurarak şikayette bulunmuşlardır. Bu davalar daha yeni görülmeye başlanmıştı ki Marko Paşa 6. sayısında yayınladığı haberler içerisinde "Bir kadın aranıyor" başlıklı yazı yayınlanmıştır. Yazının tam içeriği şöyledir:

"Tahtıma vâris olacak bir erkek çocuk doğuramadiğından karım Ferideciği talâkı selâse ile boşadım. Şimdi bir erkek çocuk doğuracak müceddet bir kadın ve yedek parçaları satın alınacaktır.

${ }^{48}$ Marko Paşa, a.g.e. 
Aranan şartlar:

1- $\quad$ Evvelce bu işte çalıştıklarına dair bonservis

2- $\quad$ Muvaffakiyetlerini gösterir belge

3- $\quad$ Eski işlerine dair iyi hal kâğı̀dı

Bu şartlarn haiz olanlarm dört cepheden çekilmiş anadan doğma resimleri, vücut ölçüleri, să̆lık raporu ve diğer vesikaları ile sarayıma müracaatlarn.

Kral Faruk" 49

"Bir kadın aranıyor" adlı başlık, diğer iki yazının görüldüğü davanın içine eklenerek yargılama devam etmiştir. Mahkemenin verdiği karar neticesinde Rıfat Ilgaz ile Aziz Nesin'e 7'şer ay hapis cezası verilmiştir ${ }^{50}$. Bu olay neticesinde Marko Paşa 16. sayısıyla kapanma mecburiyeti yaşamış, böylece 2. Dönemi de son bulmuştur.

Mahkemeye götürülen bir diğer başlık ise Marko Paşa'nın yine 2. döneminde, 10. sayıda yer alan "Markopaşanın Noel münasebetıle haşmetlû bir zata gönderdiği mesaj" adlı yazıdır. Yazının tamamı şöyledir:

"Şevketlûu efendimizin, cehennemmekân Abdülrezil hanın koltuklarında, vücudü âdilerinin bu memlekete bahşayişi rezalet olmakla devamlarna niyaz eyleriz.

Bu devri rezalette, Sayei şahanede memleketin şeş cihetinde, bahusus şehri güzinde mahsulü irfanlarından olan turfanda hıyar, milli şalgam ve bayır turpu yetiştirilmesine germi verilmiştir.

Velinimeti b'minnetimiz şeker, pirinç, et, kömür ve sair krallarımızın Allah belâlarını verdiği günleri görmekle kullarınız bahtiyar olacaktır.

Bir kere şöyle bir varakpâre çıkarmă̆a cesaretle kellei bidevletimizi tekrar koltuğumuzun altına almış bulunuyoruz. Olbapta emri ferman zâtı rezilânelerinin olmakla, boynumuz açlıktan kıldan incedir şevketlûu efendim.

$$
\text { Markopaşa" } 51
$$

Bu yazı neticesinde Marko Paşa'nın sahibi olarak gözüken Rıfat Ilgaz mahkeme huzuruna çıkmış: “Cumhurbaşkanın gıyaplarında şahıslarına hakaret ve tecavüz" 52 suçunu işlemekten 3 yıl hapis cezasına çarptırılmıştır.

\footnotetext{
${ }^{49}$ Marko Paşa, 3 Aralık 1948.

${ }^{50}$ Hür Marko Paşa, 16 Mayıs 1949, "3 yazı kaça mal oldu".

51 Marko Paşa, 31 Aralık 1948.

52 Vatan, 14 Mayıs 1949.
} 
Marko Paşa'nın 2. döneminde 11. sayısına ek olarak “Hür Marko Paşa” adlı yeni bir gazetenin ilk sayısı çıkarılmıştır. Bu yeni çıkarılan gazetenin ilk sayısının içeriği Marko Paşa'yla birebirdi. Aralarındaki tek fark Marko Paşa'nın sahibi olarak başından beri Rıfat Ilgaz gözükürken Hür Marko Paşa'nın sahipliğinde Orhan Erkip isminin yer almasıdır. Her iki gazetede yer alan "Al sözünü geriye" adlı kara mizah bölümü hem Rıfat Ilgaz'ı hem de Orhan Erkip'i tekrar mahkeme yollarına düşürmüştür.

Oldukça uzun süren mahkemede Rıfat Ilgaz ve Orhan Erkip “Büyük Millet Meclisi'ni tahkir ve tezyif" suçundan yargılanmışlardır. İlk başta temyiz kararı çıksa da sonradan bu karar bozulmuş ve dava yeniden görülmeye başlanmıştır. Mahkemenin verdiği karar neticesinde Rıfat Ilgaz'a ve Orhan Erkip'e "cumhurbaşkanına hakaret" sebebiyle 1 yıllık hapis cezası verilmiştir. Bu dava yüzünden Rıfat Ilgaz'ın sahipliği altında yayınlanan Hür Marko Paşa kapatılmıştır.

\section{Sonuç}

Marko Paşa yayınlandığı dönemde halk tarafından inanılmaz ilgi görmüştür. 10 kuruşluk gazetenin karaborsada 1 liraya satılır hale gelmesinin en büyük nedeni hükümete karşı oluşan halk memnuniyetsizliğinin en açık şekilde dışavurumunun bu gazetede dile getirilmiş olmasıdır. Halkın ne istediğini çok iyi bilen ve bizzat halkın içinden gelen yazarlar, o günün şartlarını incelemiş ve kendi düşünce süzgeçlerinden geçirerek gazeteye aktarmışlardır. Haberlerin yazımında kullanılan halk ağızı ve devlet makamlarında çalışan kişilerle sanki mahalle arkadaşları gibi sohbet ediyormuşçasına oluşturulan atmosfer Türk halkına samimi gelmiş ve bunun sonucunda da baskı ve satış rekorları kırılmıştır. İlk başta bu derece başarılı olan gazeteyi, hükümet kendi aleyhinde propaganda oluşturulmasını istemediğinden baskı yapmaya başlamıştır. Mecliste geçen konuşmalar, yazarların sürekli olarak mahkeme veya hapis yollarında bulunmaları, bir türlü çözülemeyen matbaa sorunları, tehditler, sağlık sorunları ve zamansız ölüm Marko Paşa için sıradanlaşmış kavramlardır. Gazetenin her yazarının başına muhakkak bir olay gelmiştir. Sabahattin Ali, Aziz Nesin ve Rıfat Ilgaz toplamda 8 yıl cezaevinde bulunmuşlardır. Sabahattin Ali bu yolda canını vermiş, Aziz Nesin ve Rıfat Ilgaz eşlerinden boşanarak aile hayatlarını noktalamışlardır.

Marko Paşa, ilk olarak Başbakan Recep Peker'in sonra sırasıyla Hasan Saka'nın ve Şemsettin Günaltay'ın hükümetten gitmelerini kendi zaferi olarak gazetelerinde ifade etmiştir. $O$ zamana kadar cumhurbaşkanlarının karikatürünün yapılması sakıncalı olarak gözükürken CHP'nin iktidardan ayrılması sonucu ilk kez İsmet İnönü'nün karikatürleri bütün bir sayfayı dolduracak şekilde Marko Paşa'nın ilk sayfalarında yayınlanmıştır. İktidarın değişmesiyle gazeteye yönelik baskıların biteceği beklenirken, DP'nin Marko 
Paşa aleyhinde yorumlanan hükümet programı, Medet ve Yeni Seri Hür Marko Paşa'nın kapanmalarına yol açmıştır. Büyük başarılara imza atan Marko Paşa, 4 sene gibi kısa bir sürede Türk basın hayatında büyük ses getirmiş ve adeta yorgun bir demokrasi savaşçısı olarak devrini tamamlamıştır.

Kaynakça

Yararlanılan Gazeteler

Alibaba: 9 Aralik 1947

Cumhuriyet, 13 Mart 1947.

Marko Paşa: 25 Kasım, 2, 9, 16 Aralık 1946, 10, 17, 24 Şubat, 10 Mart, 7, 28 Nisan 1947, 26 Kasım, 3, 31 Aralık 1948, 8 Şubat 1949.

Malûm Paşa: 8, 15 Eylül 1947.

Merhum Paşa: 26 Mayıs 1947.

Medet: 3 Haziran 1950.

Hür Marko Paşa: 16 Mayıs, 30 Ağustos 1949.

Hür Marko Paşa (Yeni Seri): 8, 15 Mayıs 1950.

T.C. Resmi gazete: 8 Ağustos 1931.

Vatan: 14 Mayis 1949.

Yedi-Sekiz Paşa: 29 Nisan 1949.

\section{Kitaplar}

Bezirci, Asım; Rıfat Ilgaz, Çınar Yayınları, İstanbul, 1992.

Cantek, Levent; Markopaşa Bir Mizah ve Muhalefet Efsanesi, İletişim Yayınları, İstanbul 2015.

Ilgaz, Rıfat; Sarı Yazma, Çınar Yayınları, İstanbul, 1990.

Nesin, Aziz; Geriye Kalan, Nesin Yayınevi, İstanbul, 2019.

Sami, Şemseddin; Kâmûs-1 Türkî, Çağrı Yayınları, 2014, İstanbul.

Saydur, Mehmet; Markopaşa Gerçeği, Çınar Yayınları, İstanbul, 2013.

\section{Makaleler}

Yetkin, Barış; 1945-1950 Arası "Demokratikleşme" Sürecinde Basın, 2012, Akdeniz Üniversitesi, İletişim Fakültesi.

\section{Tezler}

Kahraman Vurucu, Sema; Türkiye'nin Değişim Yıllarında Siyasi Mizahla Muhalefet Örneği: Marko Paşa Gazetesi, Yüksek Lisans Tezi, 
Marmara Üniversitesi, Sosyal Bilimler Enstitüsü, Gazetecilik Anabilim Dalı, Genel Gazetecilik Bilim Dalı, İstanbul, 2013.

\section{Zabit Cerideleri}

TBMM Tutanak Dergisi, 4 Aralık 1946, 8. Dönem, Cilt:8.

TBMM Tutanak Dergisi, 29 Mayıs 1950, 9. Dönem, Cilt: 1. 